\title{
Simulating the trajectory of off-pump surgery: The heroic defense of the homograft
}

\author{
Ari A. Mennander, MD, PhD
}

\author{
From Tampere University Heart Hospital and Tampere University, Tampere, Finland. \\ Disclosures: Author has nothing to disclose with regard to commercial support. \\ Received for publication May 26, 2018; revisions received May 26, 2018; accepted for publication May 30, 2018; \\ available ahead of print July 13, 2018. \\ Address for reprints: Ari A. Mennander, MD, PhD, Tampere University Heart Hospital, SDSKIR, Tampere PL \\ 2000, Finland (E-mail: ari.mennander@sydansairaala.fi). \\ J Thorac Cardiovasc Surg 2019;157:51-2 \\ $0022-5223 / \$ 36.00$ \\ Copyright $(2018$ by The American Association for Thoracic Surgery \\ https://doi.org/10.1016/j.jtcvs.2018.05.112
}

Off-pump surgery seemed to be the ultimate answer for the universal treatment of patients with coronary artery disease. Soon, accumulating scientific reports revealed that conventional coronary bypass surgery may still be safer with better long-term results. For many surgeons, off-pump surgery is now reserved to a minority with extreme aortic calcification that is not amenable to other intervention.

What about surgery for endocarditis using cryopreserved homografts? Is the homograft the ultimate solution for the treatment of aortic root abscesses or does the homograft remain a fancy technical peculiarity to treat endocarditis in intravenous drug users? Many institutions lack the homograft from their armament for simple reasons: The homografts are expensive, their use requires technical expertise, there is an increased risk for anti-human leukocyte antigen antibody formation and early graft degradation, and, above all, the conventional prosthesis is readily available. ${ }^{2}$

The current article by Sultan and colleagues ${ }^{3}$ describes the outcome of aortic root replacement with cryopreserved aortic homograft among a selected patient group of 138 intravenous drug users with infective endocarditis. The patients had several comorbidities, and many had undergone previous surgery. Eleven of the patients underwent reexploration for bleeding, 5 patients experienced a permanent stroke, 21 patients required postoperative dialysis for renal failure, and 21 patients received a permanent pacemaker. Early mortality occurred in 17 patients, and altogether 47 patients died during a short mean follow-up of 2.4 years.

It should make sense to use a homograft after extensive debridement due to endocarditis. The infected aortic root abscess and valve need thorough debridement, and the homograft without synthetic material compensates for the loss of tissue and prevents the recurrence of infection. ${ }^{4}$ The pliable tissue characteristics of the homograft allows creative means to reconstruct the deficient tissue. ${ }^{3,5}$ The article rightfully highlights the surgical expertise of the authors.

The results of the study cannot demonstrate the superiority of the homograft over other prostheses, because other

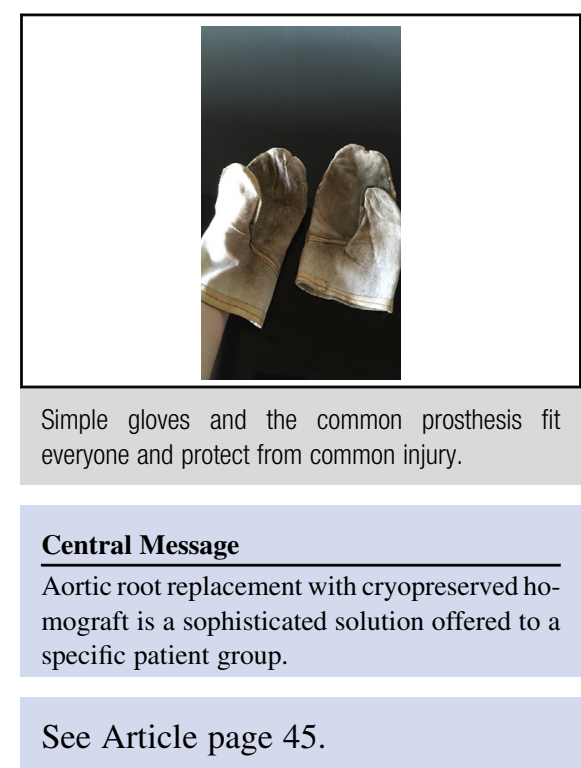

prosthesis types were not compared. Reuse of intravenous drugs after surgery was not investigated. Most of the patients did not have extensive aortic root abscess, although obviously it is difficult to quantify the extent of the infected tissue. ${ }^{5}$ Likewise, Sabik and colleagues ${ }^{6}$ reported that aortic homografts were associated with low recurrent infection, but again no comparison was made between other prosthesis types.

Although cryopreserved homografts offer excellent hemodynamic characteristics, increased resistance to infection, and decreased thromboembolic events after surgery for the aortic valve, ${ }^{4,6,7}$ many a surgeon has not adopted these special grafts in practice. The need of homografts for active aortic valve infections has dramatically decreased by time, because there is no clear evidence supporting the pragmatic use of homografts for endocarditis. $^{5,8}$ The increase of intravenous drug use justifies an individual treatment protocol, and special emphasis has been given to modern antibiotic treatment and radical debridement. ${ }^{9,10}$ A multidisciplinary approach on dealing with the underlying causes of the problem related to intravenous drug abuse also may prove effective. ${ }^{9}$ Sultan and colleagues ${ }^{3}$ conclude fairly that the homograft is an option during surgery for endocarditis.

\footnotetext{
References

1. Adams DH, Chikwe J. On-pump CABG in 2018. J Am Coll Cardiol. 2018;6: 992-3.
} 
2. Kirklin JK. Challenging homografts as the holy grail for aortic valve endocarditis. J Thorac Cardiovasc Surg. 2016;151:1230-1.

3. Sultan I, Bianco V, Kilic A, Chu D, Navid F, Gleason TG. Aortic root replacement with cryopreserved homograft for infective endocarditis in the modern North American opioid epidemic. J Thorac Cardiovasc Surg. 2019; $157: 45-50$.

4. Preventza O, Mohamed AS, Cooley DA, Rodriguez V, Bakaeen FG, Cornwell LD, et al. Homograft use in reoperative aortic root and proximal aortic surgery for endocarditis: a 12-year experience in high-risk patients. J Thorac Cardiovasc Surg. 2014;148:989-94.

5. Kim JB, Ejiofor JI, Yammine M, Camuso JM, Walsh CW, Ando M, et al. Are homografts superior to conventional prosthetic valves in the setting of infective endocarditis involving the aortic valve? J Thorac Cardiovasc Surg. 2016;151: $1239-48$.
6. Sabik JF, Lytle BW, Blackstone EH, Marullo AG, Pettersson GB, Cosgrove DM. Aortic root replacement with cryopreserved allograft for prosthetic valve endocarditis. Ann Thorac Surg. 2002;74:650-8.

7. Steffen V, Marsch G, Burgwitz K, Kuehn C, Teebken OE. Resistance to infection of long-term cryopreserved human aortic valve allografts. J Thorac Cardiovasc Surg. 2016;151:1251-9.

8. Savage EB, Saha-Chaudhuri P, Asher CR, Brennan JM, Gammie JS. Outcomes and prosthesis choice for active aortic valve infective endocarditis: analysis of the Society of Thoracic Surgeons adult cardiac surgery database. Ann Thorac Surg. 2014;98:806-14.

9. Ferraris VA, Sekela ME. Missing the forest for the trees: the world around us and surgical treatment of endocarditis. J Thorac Cardiovasc Surg. 2016;152:677-80.

10. Feindel CM. It's not what you put in that is important, it's what you take out. J Thorac Cardiovasc Surg. 2016;151:1249-50. 